\title{
Istorija otečesvennogo gosudarstva i prava. Četvertoe izdanije, pererabotannoe i dopolnenoe, pod redakcijej doktora iuridi- českich nauk, zaslužennogo profesora MGU, laureata Gosu- darstvennoi premii Rossijskoj Federacji O. I. Čistiakova, wyd. Iurist, Moskva 2006, čast' 1, ss. 477, čast' 2, 510 stron.
}

Każdy dobrze napisany podręcznik powinien odzwierciedlać istniejący stan badań naukowych nad daną dziedziną nauki. $Z$ wielkim zainteresowaniem sięgnąłem więc do dwutomowego podręcznika pod redakcją O. I. Czistiakowa, chcąc zorientować się w kierunkach rozwoju rosyjskiej historiografii prawa po upadku państwa radzieckiego. Nieżyjący już prof. Czistiakow, zajmujący się konstytucjonalizmem radzieckim, kierował katedrą historii ojczystego państwa i prawa na moskiewskim uniwersytecie im. Łomonosowa, a recenzowany, obszerny podręcznik jest wspólnym dziełem jego i jego współpracowników. Czistiakow, oprócz autorstwa kilku rozdziałów, jako redaktor jest autorem obszernego wstępu oraz konkludujących zakończeń wszystkich rozdziałów. Przyjąć więc należy, że recenzowany podręcznik jest reprezentatywny dla obecnego stanu badań, skoro pochodzi z najważniejszego rosyjskiego środowiska naukowego, jest współcześnie wydany, a recenzowane wydanie (wprawdzie czwarte) zostało „przepracowane i uzupełnione".

W obszernym wstępie redaktor przedstawia podstawowe założenia metodologiczne. Podkreślony został ścisły związek między państwem i prawem, gdyż powstają one jednocześnie, rozwijają się w dialektycznym związku i wzajemnej zależności. Ci zaś prawnicy, którzy obecnie twierdzą, że prawo może istnieć bez państwa, mylą prawo z moralnością. Ta marksistowska teza rzutuje na układ podręcznika - części dotyczące historii ustroju społecznego i politycznego są zdecydowanie bardziej obszerne niż te, które dotyczą historii źródeł prawa i historii prawa. Ponadto podstawą periodyzacji są dzieje ustroju, które bardzo często, jak łatwo się zorientować, w ogóle nie pasują do periodyzacji dziejów prawa. Warto także zauważyć, że dużą część podręcznika, szczególnie w tomie 2, zajmują wprowadzenia opisujące aktualny kontekst polityczny. Podręcznik obejmuje okres do upadku ZSRR i realizuje ambitne założenie przedstawienia różnych form państwowości na terenie państwa rosyjskiego, także tych, które nie miały nic wspólnego z dziejami narodu rosyjskiego. Dlatego wykład dziejów „ojczystego” państwa i prawa rozpoczyna się od starożytnego państwa Urartu, istniejącego na pograniczu Armenii i Turcji w IX-VI w. p.n.e. $W$ dalszych partiach podręcznika zostały omówione między innymi państwowość i prawo Wielkiego Księstwa Litewskiego, Kurlandii, Kazachstanu oraz Zakaukazia.

Lektura pierwszej części podręcznika powoduje niedosyt przede wszystkim z powodu fragmentarycznych informacji o dawnym prawie ruskim. Odnosi się wrażenie, że przedstawione informacje nie są bardziej rozbudowane niż te, które u nas są przekazywane w ramach wykładu powszechnej historii prawa. Dotyczy to na przykład wzmianek 
o Ruskiej Prawdzie, sudiebnikach i Sobornym Ułożeniju. W kontekście tego ostatniego pomnika prawa podręcznik odnotowuje (ale marginalizuje) wpływ prawa litewskiego na powstanie Sobornego Ułożenia.

Polskiego czytelnika interesują te wątki wykładu, które są związane z naszymi dziejami państwa i prawa. Występują one w ramach opisu „zbierania ziem ruskich” i powrotu tych ziem do „Matki Ojczyzny”. Szczególnie dużo miejsca poświęcono włączeniu Zadnieprza do Rosji w II poł. XVII w. Zostało ono przedstawione jako rezultat walki narodu ukraińskiego o zrzucenie panowania polskich feudałów. Dowiadujemy się, że lud ukraiński został wyzwolony z jarzma polskich feudałów, natomiast podręcznik nie wyjaśnia, czy w rezultacie tego wydarzenia nastąpiła poprawa położenia ukraińskiego chłopstwa. Możemy się jednak dowiedzieć, że na zajętym terytorium utrzymano polskie prawo - co więcej - w I poł. XVIII w. podjęto próbę kodyfikacji prawa Ukrainy na bazie polskiego i litewskiego prawa. Podręcznik nie wyjaśnia powodów utrzymywania prawa „pańskiej” Polski.

Dużo miejsca poświęcono ponadto Królestwu Polskiemu w latach 1815-1830. Podkreślono liberalny charakter konstytucji, którą car „nawet zaprzysiągł”. Polacy byli jednak z tych praw niezadowoleni, chcieli odbudowy Rzeczypospolitej i dlatego wywołali powstanie, skutkiem czego utracili konstytucję. Według podręcznika Królestwo Polskie było źródłem licznych niepokojów nawet w XX w. - jest to jedyna wzmianka o dalszych dziejach ziem polskich w składzie Cesarstwa. O procesie rusyfikacji ziem nie ma ani słowa. Tak samo potraktowano zresztą Finlandię. Podsumowując stwierdzono, że ani Finlandia, ani Polska nie były koloniami Rosji, a korzystały z dobrodziejstw rozwoju gospodarczego imperium w XIX w.

Wydawać by się mogło, że przedstawiona w pierwszym tomie optymistyczna wizja dziejów Rosji - jednoczycielki pod rządami caratu - będzie nie do pogodzenia z pochwałą systemu, który carat zniszczył, czyli Związku Radzieckiego. Nic bardziej błędnego. Cały tom II jest wielką apoteozą ZSRR jako najwyższego osiągnięcia państwowości rosyjskiej. Prezentowane opinie mają wręcz stalinowski rodowód. Przykładowo, podręcznik usprawiedliwia represje wobec „kułaków” tym, że niszczyli oni swój dobytek. Podobnie wymordowanie wyższych dowódców armii wynikało z faktu, iż w tej grupie znajdowało się wielu zwolenników kontrrewolucjonisty Lwa Trockiego, którego uważali oni za faktycznego przywódcę w czasie wojny domowej - nie można im więc było ufać.

Autorzy podręcznika są nawet w stanie usprawiedliwić pakt Ribbentrop-Mołotow oraz uzasadnić przyłączenie państw bałtyckich do ZSRR. To ostatnie odbyło się na prośbę narodów bałtyckich, które nie mogły się swobodnie rozwijać w ramach swoich małych państw i dążyły do poprawy położenia gospodarczego w ramach ZSRR, a ponadto poszukiwały ochrony przed faszystowskimi Niemcami. Podobnie włączenie wschodniej Polski do ZSRR było jedynie powrotem ziem zachodniej Białorusi i Ukrainy do odpowiednich republik radzieckich, a przedstawianie włączenia tych ziem jako wyniku rozbioru Polski między hitlerowskie Niemcy i ZSRR „nie odpowiada rzeczywistości”. Podręcznik podaje także fałszywą informację, jakoby drogą układu między Polską a ZSRR 
po wojnie doszło do wymiany obwodu białostockiego (który został przekazany Polsce) na obszar w okolicy miasta Włodzimierz Wołyński.

Na tle opisanych interpretacji historii ZSRR powstaje pytanie, czy przedstawiają one jakąkolwiek wartość naukową. Nie jestem w stanie na to pytanie udzielić odpowiedzi. Dla badacza dużą wartość przedstawia zebrany w tomie wykaz literatury historyczno-prawnej - i prawdopodobnie nic więcej.

Problem dotyczący recenzowanego podręcznika polega jednak przede wszystkim na tym, że jest on źródłem wiedzy dla studentów prawa. W zakończeniu prof. Czistiakow pisze: „Niejednokrotnie Ruś znajdowała się w ciężkim położeniu. Jednak po strasznych doświadczeniach ona się znowu dźwigała, ustanawiając swoje prawa i niosąc wyzwolenie innym narodom. Obecnie nasz kraj znowu przeżywa ostry kryzys. I od ciebie, młody czytelniku, któremu sądzone jest wzięcie za pięć lat w swoje ręce roli rządzenia państwem, zależy, czy nasza Ojczyzna osiągnie pełen rozkwit, czy będzie znowu potężna (mogučaja) i piękna”. Pytanie, czy na fałszu można budować przyszłość, jest mało istotne. Wyjaśnił to zresztą prezydent Władimir Putin, który na spotkaniu z historykami 27 listopada 2003 r. mówił: „Fakty, o których mowa w podręcznikach, powinny budować uczucie dumy z historii naszego kraju. Do niedawna historycy kładli nacisk na sprawy negatywne, gdyż ich zadaniem było burzenie poprzedniego systemu. Teraz mamy inne, twórcze zadania. Musimy przy tym usunąć plewy i szumowiny, które się przez te lata nawarstwiły"'. I wszystko jasne.

Piotr Fiedorczyk

${ }^{1}$ Cyt. za: K. Kurczab-Redlich, Głowa w mur Kremla, Warszawa 2007, s. 123. 